\title{
Measurement of the Anticancer Agent Gemcitabine and Its Deaminated Metabolite at Low Concentrations in Human Plasma by Liquid Chromatography-Mass Spectrometry
}

\author{
Yan Xu \\ Cleveland State University, y.xu@csuohio.edu \\ Bruce Keith \\ National Cancer Institute \\ Jean L. Grem \\ National Cancer Institute
}

Follow this and additional works at: https://engagedscholarship.csuohio.edu/scichem_facpub

Part of the Analytical Chemistry Commons

How does access to this work benefit you? Let us know!

\section{Recommended Citation}

Xu, Yan; Keith, Bruce; and Grem, Jean L., "Measurement of the Anticancer Agent Gemcitabine and Its Deaminated Metabolite at Low Concentrations in Human Plasma by Liquid Chromatography-Mass Spectrometry" (2004). Chemistry Faculty Publications. 202.

https://engagedscholarship.csuohio.edu/scichem_facpub/202

This Article is brought to you for free and open access by the Chemistry Department at EngagedScholarship@CSU. It has been accepted for inclusion in Chemistry Faculty Publications by an authorized administrator of EngagedScholarship@CSU. For more information, please contact library.es@csuohio.edu. 


\title{
Measurement of the anticancer agent gemcitabine and its deaminated metabolite at low concentrations in human plasma by liquid chromatography-mass spectrometry
}

\author{
Yan Xu Bruce Keith Jean L. Grem
}

\section{Introduction}

Gemcitabine (Gemzar ${ }^{\mathbb{R}}$, Eli Lilly, Indianapolis, IN, USA; $2^{\prime}, 2^{\prime}$-difluoro-2'-deoxycytidine, $\mathrm{dFdC}$ ) is an analog of deoxycytidine (Fig. 1), which exhibits a broad spectrum of anti-neoplastic activity [1-3]. $\mathrm{dFdC}$ enters cells through nucleoside transporters, where it is phosphorylated to a $5^{\prime}$-monophosphate (dFdCMP) by deoxycytidine kinase in a rate-limiting reaction (Fig. 2). The subsequent phosphorylations by UMP/CMP monophosphate kinase and nucleoside diphosphate kinase (NDK) generate the active $5^{\prime}$-diphosphate (dFdCDP) and $5^{\prime}$-triphosphate (dFdCTP) nucleosides. The cytotoxic effects of $\mathrm{dFdC}$ are attributed to the combined actions of $\mathrm{dFdCDP}$, which inhibits ribonucleotide reductase, and $\mathrm{dFdCTP}$, which is incorporated into DNA and results in chain termination [4]. $\mathrm{dFdC}$ is deaminated by cytidine deaminase to its inactive metabolite $2^{\prime}, 2^{\prime}$-difluoro-2'-deoxyuridine ( $\left.\mathrm{dFdU}\right)$.

Clinically, $\mathrm{dFdC}$ is used to treat a wide variety of solid tumors, both as a single agent and in combination with other cytotoxic agents. As a single agent, it is most commonly administered intravenously weekly at dose of $1000 \mathrm{mg} / \mathrm{m}^{2}$ by $30 \mathrm{~min}$ infusion. To measure $\mathrm{dFdC}$ and $\mathrm{dFdU}$ in plasma samples from cancer patients receiving $\mathrm{dFdC}$ with the usual 
<smiles></smiles>

Gemcitabine (dFdC) $\mathrm{MW}=263$<smiles>O=CC1C=CN2C(O)C(O)C(F)(F)C2O1</smiles>

2',2'-Difluoro-2'-Deoxyuridine (dFdU)

$\mathrm{MW}=264$<smiles>CC1OC2C(=O)NC(=O)C(F)=CN2C1O</smiles>

5'-Deoxy-5-Fluorouridine (5'-DFUR) $\mathrm{MW}=246$

Fig. 1. The chemical structures of $\mathrm{dFdC}, \mathrm{dFdU}$ and internal standard.

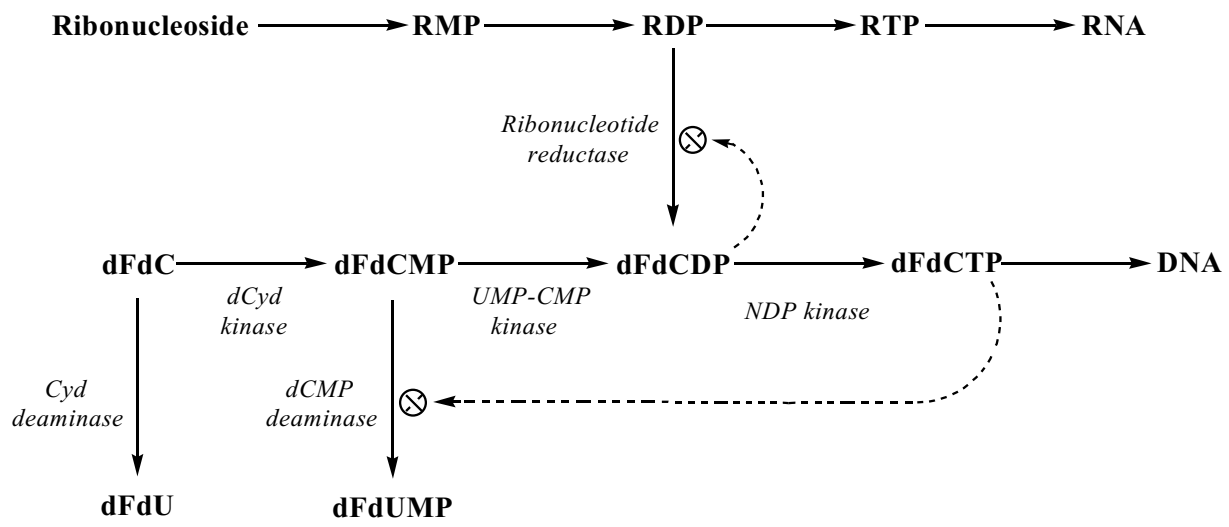

Fig. 2. Metabolism of gemcitabine.

dosing regimens, both normal-phase and reversed-phase liquid chromatography with ultraviolet detection (LC-UV) methods have been developed [5-8].

A Phase I trial of weekly dFdC given as 24-h infusion followed by a 24-h infusion of $5^{\prime}$-fluoro- $2^{\prime}$-deoxyuridine (floxuridine, FUDR ${ }^{\circledR}$, Roche Laboratories, Nutley, NJ, USA) and oral calcium leucovorin was conducted in our clinic. This trial was implemented based on the following considerations: (a) the efficacy of $\mathrm{dFdC}$ is schedule dependent and continuous infusion is more effective than bolus injection in xenograft models [9]; (b) our studies showed that the administration of $\mathrm{dFdC}$ followed by 5-FU led to more than additive cytotoxicity and enhanced DNA damage in a human colon cancer cell line [10]; (c) the pharmacologic data revealed that $\mathrm{dFdC}$ has a very short half-life (median $8 \mathrm{~min}$ in one study) [7,8]; and (d) the conversion of $\mathrm{dFdC}$ to $\mathrm{dFdCMP}$ is saturable $[11,12]$. To ensure the tolerability of $\mathrm{dFdC}$, patients received an initial cycle of $\mathrm{dFdC}$ as $24 \mathrm{~h}$ infusion weekly for 3 weeks out of four. A prior Phase II study of $\mathrm{dFdC}$ given as weekly $24-\mathrm{h}$ infusion suggested that $180 \mathrm{mg} / \mathrm{m}^{2}$ was the maximum tolerated dose [12]; the starting dose for our trial was $150 \mathrm{mg} / \mathrm{m}^{2}$. If tolerated, FUDR and oral calcium leucovorin were added to the subsequent cycle.

Because the plasma concentrations of $\mathrm{dFdC}$ in the 24-h infusion study were anticipated to be below or near the limits of quantitation of the liquid chromatography (LC)-UV methods, a more sensitive and specific analytical method was therefore needed. This work describes the development and validation of a liquid chromatography/mass spectrometry (LC-MS) method for the determination of $\mathrm{dFdC}$ and its deaminated metabolite $\mathrm{dFdU}$ in human plasma at low concentrations.

\section{Experimental}

\section{Chemicals and solutions}

Gemcitabine (dFdC) was supplied by the Cancer Therapy Evaluation Program at the National Cancer Institute (Bethesda, MD, USA). It was formulated by Eli Lilly as a lyophilized product containing the equivalent of 200 or $1000 \mathrm{mg}$ gemcitabine (LY188011) as the hydrochloride salt. $2^{\prime}, 2^{\prime}$-Difluoro-2'-deoxyuridine (dFdU) was provided by Lilly Research Laboratories (Indianapolis, IN, USA) through a material transfer agreement with the National Cancer Institute. The internal standard, $5^{\prime}$-deoxy-5-fluorouridine (5'-DFUR), was obtained from Sigma (St. Louis, MO, USA). Ammonium acetate was from Aldrich (Milwaukee, WI, USA). HPLC grade water and methanol were from Fisher (Fair Lawn, NJ, USA). Tetrahydrouridine (Lot No. 112907-J/22) was provided by the Drug Synthesis and 
Chemistry Branch at the National Cancer Institute. Pooled donor plasma was provided by the Department of Transfusion Medicine, Warren G. Magnusen Clinical Center, National Institutes of Health (Bethesda, MD, USA).

A stock solution of ammonium acetate $(100 \mathrm{mM}, \mathrm{pH} 6.8)$ was prepared by dissolving appropriate amounts of ammonium acetate in a known volume of HPLC grade water. Five millimolar ammonium acetate at $\mathrm{pH} 6.8$ was prepared by 1:20 dilution of the stock solution with HPLC grade water.

Standard stock solutions of dFdC and dFdU $(10.0 \mathrm{mg} / \mathrm{ml})$, and the internal standard stock solution of $5^{\prime}$-DFCR $(500 \mu \mathrm{g} / \mathrm{ml})$ were prepared by dissolving appropriate amounts of compounds in known volumes of methanol. Standard mixture working solutions of $\mathrm{dFdC}$ and $\mathrm{dFdU}$ at the concentrations of $0.0500,0.100,0.500,1.00,5.00,10.0$, 20.0 and $50.0 \mu \mathrm{g} / \mathrm{ml}$ were prepared by mixing and serial dilutions of the stock solutions with methanol. The internal standard working solution $(5.00 \mu \mathrm{g} / \mathrm{ml})$ was prepared by 100 -fold dilution of the stock solution with methanol.

\section{Blank plasma, plasma standards and patient samples}

Pooled donor plasma containing $1 \mu \mathrm{M}$ tetrahydrouridine was used as the blank plasma in this study. To prepare plasma standards, $50 \mu \mathrm{l}$ of standard mixture working solutions of $\mathrm{dFdC}$ and $\mathrm{dFdU}$ at each concentration level and $50 \mu \mathrm{l}$ of internal standard solution $\left(5^{\prime}\right.$-DFUR, $\left.5.00 \mu \mathrm{g} / \mathrm{ml}\right)$ were added to $1.5-\mathrm{ml}$ centrifuge tubes (Marsh Bio Products Inc., Rochester, NY, USA). After the solutions were dried at $30^{\circ} \mathrm{C}$ for $20 \mathrm{~min}$ in an Eppendorf Vacufuge ${ }^{\mathrm{TM}}$ (Brinkmann Instruments, Westbury, NY, USA), $500 \mu \mathrm{l}$ of blank plasma was added to each tube. The resultant plasma standards $(\mathrm{dFdC}$ and $\mathrm{dFdU}$ ) were at the concentrations of 5.00, 10.0, $50.0,100,500,1000,2000$ and $5000 \mathrm{ng} / \mathrm{ml}$ with a fixed concentration of internal standard 5'-DFUR $(500 \mathrm{ng} / \mathrm{ml})$.

To prepare patient plasma samples, aliquots of $50-\mu 1$ internal standard solution ( $5^{\prime}$-DFUR, $\left.5.00 \mu \mathrm{g} / \mathrm{ml}\right)$ were added to $1.5-\mathrm{ml}$ centrifuge tubes. After the solutions were dried at $30^{\circ} \mathrm{C}$ for $20 \mathrm{~min}$ in the Eppendorf Vacufuge $\mathrm{e}^{\mathrm{TM}}, 500 \mu \mathrm{l}$ of patient plasma was added to each tube.

The above blank plasma, plasma standards, and patient samples were subjected to solid phase extraction prior to the instrumental analysis.

\section{Solid phase extraction}

Oasis ${ }^{\circledR}$ HLB $\left(3 \mathrm{~cm}^{3}\right)$ solid phase extraction cartridges (Waters Corporation, Milford, MA, USA) were used for sample preparation. A $500 \mu \mathrm{l}$ plasma sample containing $250 \mathrm{ng}$ of internal standard was first diluted with an equal volume of calcium- and magnesium-free phosphate buffered saline (PBS, 1×, pH 7.4) (Invitrogen/Gibco, Grand Island, NY, USA). The Oasis ${ }^{\circledR}$ HLB cartridge was conditioned with $3 \mathrm{ml}$ methanol and then $3 \mathrm{ml}$ PBS. After loading the sample, the cartridge was washed with $2 \mathrm{ml}$ PBS and dried with air. The analytes were eluted from the cartridge with
$2 \mathrm{ml}$ methanol. The eluate was collected in a glass tube $(12 \mathrm{~mm} \times 75 \mathrm{~mm})$ and dried in the Eppendorf Vacufuge ${ }^{\mathrm{TM}}$ at $30^{\circ} \mathrm{C}$ for $2 \mathrm{~h}$. The residue was reconstituted in $500 \mu \mathrm{l}$ HPLC-grade water and re-suspended. Reconsitution of the residue was carried out in $37^{\circ} \mathrm{C}$ water bath for $5 \mathrm{~min}$ to insure complete hydration. After filtering with a GHP Acrodisc ${ }^{\circledR}$ syringe filter $(0.45 \mu \mathrm{m} \times 13 \mathrm{~mm})$ (Pall Gelman Laboratory, Ann Arbor, MI, USA), the solution was transferred to an autosampler vial (Waters, Part No. 186000326) for the instrumental analysis.

\section{Instrumentation}

The instrumentation system consisted of a Waters 2690 separations module, a Micromass Platform LC mass spectrometric detector (electrospray ionization mode (ESI)-MS) (Waters, Milford, MA, USA), and a personal computer station with MassLynx NT (Version 3.4) software (Micromass, Manchester, UK). The analytical column was a Waters $\mathrm{YMC} \mathrm{ODS}-\mathrm{AQ}^{\mathrm{TM}}(5 \mu \mathrm{m}, 120 \AA$ A $2.0 \mathrm{~mm} \times 150 \mathrm{~mm}$, Part \# AQ12S051502WT) column, which was preceded by a SecurityGuard guard column (Part \# KJO-4282) (Phenomenex, Torrance, CA, USA). The eluate from the analytical column was diverted to the ESI-MS and to the waste via a PEEK microvolume connector (Cat. \# MT1XCPK) (Valco Instruments, Houston, TX) with a post-column split ratio of 1:2. The smaller flow went to the ESI-MS and the larger one to the waste. High pressure PEEK tubing was used for all connections. The tubing prior to the inlet of the analytical column was $1 / 16$ in. o.d. and 0.01 in. i.d., and the tubing after the analytical column was $1 / 16$ in. o.d. and 0.005 in. i.d.

\section{Chromatographic conditions}

The Waters 2960 separations module were operated under the following conditions: sample temperature, $4( \pm 1)$ ${ }^{\circ} \mathrm{C}$; analytical column temperature, $30( \pm 10){ }^{\circ} \mathrm{C}$; sample injection volume, $50 \mu \mathrm{l}$. A gradient elution method was used with two solvents: solvent A was $5 \mathrm{mM}$ ammonium acetate at pH 6.8 and solvent B was HPLC-grade methanol. The initial composition of the mobile phase was $98 \%$ solvent $\mathrm{A} / 2 \%$ solvent $\mathrm{B}(\mathrm{v} / \mathrm{v})$. An isocratic gradient was used at $0.2 \mathrm{ml} / \mathrm{min}$ for $3 \mathrm{~min}$, followed by a linear gradient over $4 \mathrm{~min}$ to $70 \%$ solvent $\mathrm{A} / 30 \%$ solvent $\mathrm{B}$. The gradient returned to the initial conditions by a linear gradient over $2 \mathrm{~min}$ and remained there for $6 \mathrm{~min}$ prior to the next injection. The analytical column was equilibrated with the initial separation conditions prior to the initial injection. The total run time for a LC-MS analysis was $15 \mathrm{~min}$ per sample.

\section{ESI-MS detection}

The mass spectrometer was operated in the negative electrospray ionization mode. It was tuned by the infusion of an analyte mixture $(100.0 \mu \mathrm{g} / \mathrm{ml}$ each in $5 \mathrm{mM}$ ammonium acetate, $\mathrm{pH}$ 6.8) with a Harvard syringe pump (Harvard 
Apparatus, South Natick, MA, USA, Cat. No. 55-1111) at flow rate of $5.0 \mu \mathrm{l} / \mathrm{min}$ via a 0.005 in. i.d. PEEK tubing. The tuning sample was converged with the incoming LC mobile phase $(98 \%$ of $5 \mathrm{mM}$ ammonium acetate at $\mathrm{pH}$ $6.8+2 \%$ methanol at a flow rate of $0.2 \mathrm{ml} / \mathrm{min}$ before the post-column split) in a sample tee prior to the MS detection. The optimized ionization conditions were: analytical vacuum, $<1.0 \times 10^{-4} \mathrm{mbar}$; nitrogen gas, $400 \mathrm{l} / \mathrm{h}$; capillary,

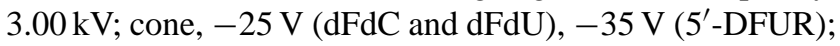
ion source temperature, $140^{\circ} \mathrm{C}$; low- and high-mass resolution, 15.0; ion energy, $0.8 \mathrm{~V}$; and multiplier, $-650 \mathrm{~V}$.

Full-scan spectra were acquired in the continuum mode over the mass range of 230-270 amu at a scan rate $200 \mathrm{amu} / \mathrm{s}$. Single-ion-monitoring (SIM) mode was used for analyte quantitation by simultaneously monitoring quasi-molecular ions, $\mathrm{m} / \mathrm{z} 245$ for $\left[5^{\prime} \text {-DFUR-H }\right]^{-}, \mathrm{m} / \mathrm{z} 262$ for $[\mathrm{dFdC}-\mathrm{H}]^{-}$, and $\mathrm{m} / z 263$ for [dFdU-H] ${ }^{-}$. Data acquisition was carried out with a dwell time of $0.50 \mathrm{~s}$, a span of $0.00 \mathrm{Da}$, a repeat of 1 , and an inter channel delay of $0.05 \mathrm{~s}$. The cone voltages were 35,25 , and 25 for $m / z 245,262$, and 263 , respectively.

\section{Data analysis}

Micromass MassLynx NT (Version 3.4) software was used for acquisition of the LC-MS data, construction of the internal calibration curves, and derivation of the regression equations. The $\mathrm{dFdC}$ and $\mathrm{dFdU}$ concentrations in plasma samples were determined by the regression equations after obtaining the peak area ratios of the unknowns to the internal standard from their mass chromatograms.

The area under the curve (AUC) was determined by non-compartmental methods using a continuous intravenous infusion model with WinNonLin ${ }^{\mathrm{TM}}$ (Version 4.0) (Pharsight Corp., Mountain View, CA, USA). Clearance was calculated by dividing the dose rate by the steady-state.

\section{Method validation}

The recoveries were determined by comparing mean peak areas of the plasma samples prepared by spiking the blank plasma with known concentrations of $\mathrm{dFdC}, \mathrm{dFdU}$ and $5^{\prime}$-DFUR to the mean the peak areas of the control samples prepared by spiking $\mathrm{dFdC}, \mathrm{dFdU}$ and $5^{\prime}$-DFUR at the same levels in $5 \mathrm{mM}$ ammonium acetate solution $(\mathrm{pH}$ 6.8). The intra- and inter-assay precisions were determined by analyzing the plasma samples with known concentrations of $\mathrm{dFdC}$ and $\mathrm{dFdU}$ within run and from different runs. The linearities of the calibration curves were assessed by the correlation coefficients. The limits of quantitation were calculated by 10 times of signal-to-noise ratio.

\section{Patient blood sampling}

Eight adult patients with advanced cancer were enrolled in an Institutional Review Board-approved Phase I trial involving $\mathrm{dFdC}$ as 24 -h infusion weekly for three of 4 weeks. All patients provided written, informed consent. Blood samples were collected prior to $(0 \mathrm{~h})$ the infusion and at the steady state during the infusion (22- and 23-h) in 10-ml green-top heparinized Vacutainer ${ }^{\circledR}$ tubes (Becton Dickinson and Company, Franklin Lakes, NJ, USA) containing $10 \mathrm{nmol}$ tetrahydrouridine as a cytidine deaminase inhibitor. The samples tubes were immediately placed on ice and centrifuged for $10 \mathrm{~min}$ at $800 \mathrm{~g}\left(4^{\circ} \mathrm{C}\right)$. The plasma was then transferred into three labeled Nalgene ${ }^{\circledR}$ cryogenic vials (Nalge Nunc International, Rochester, NY, USA) and stored at $-70^{\circ} \mathrm{C}$ until analysis.

\section{Results and discussion}

\section{ESI-MS detection}

Fig. 3 shows the full-scan ESI mass spectra of dFdC, dFdU and internal standard $5^{\prime}$-DFUR, which indicated that detection of these compounds could be achieved by monitoring quasi-molecular ions $[\mathrm{dFdC}-\mathrm{H}]^{-}$at $\mathrm{m} / \mathrm{z} 262$, [dFdU-H] $]^{-}$at $\mathrm{m} / \mathrm{z}, 263$, and $\left[5^{\prime} \text {-DFUR-H] }\right]^{-}$at $\mathrm{m} / \mathrm{z} 245$. Hence, these ions were selected for SIM detection in the subsequent quantitative analysis. Although, the difference of $\mathrm{m} / \mathrm{z}$ between $[\mathrm{dFdC}-\mathrm{H}]^{-}$and $[\mathrm{dFdU}-\mathrm{H}]^{-}$was only by 1 , the specificity of the method could be further secured by choosing the proper chromatographic conditions.

\section{Chromatographic conditions}

A YMC ODS- $\mathrm{AQ}^{\mathrm{TM}}$ reversed-phase column and a gradient elution method were used for the separation of $\mathrm{dFdC}$, $\mathrm{dFdU}$ and $5^{\prime}$-DFUR in human plasma. As shown in our previous studies [13], the column is well suited for the separation of nucleosides. In the current study, $\mathrm{dFdC}, \mathrm{dFdU}$ and $5^{\prime}$-DFUR were completely resolved from each other and from endogenous compounds by the YMC ODS- $\mathrm{AQ}^{\mathrm{TM}}$ column with retention times of $11.46,12.63$ and $13.58 \mathrm{~min}$, respectively (Fig. 4).

\section{Solid phase extraction and recovery of analytes}

We had previously reported that liquid-liquid extraction with two sequential acetonitrile applications yielded the recovery of $\geq 70.0 \%$ for $\mathrm{dFdC}$, and $\geq 81.8 \%$ for $\mathrm{dFdU}$ [6]. To simplify the procedure, the Waters polymer-based Oasis ${ }^{\circledR}$ HLB $\left(3 \mathrm{~cm}^{3}\right)$ extraction cartridge was evaluated for plasma sample preparation. Using this preparatory method, the absolute recoveries of $\mathrm{dFdC}, \mathrm{dFdU}$ and internal standard $5^{\prime}$-DFUR from human plasma were found to be $\geq 86.8,82.2$ and $97.5 \%$, respectively (Table 1 ), and the recovery data were rather consistent throughout the concentration range studied $(50.0,500,5000 \mathrm{ng} / \mathrm{ml})$. As compared with our liquid-liquid extraction procedure, the solid-phase extraction with Oasis ${ }^{\circledR}$ HLB cartridge is simple, easy to handle, and highly reproducible. 

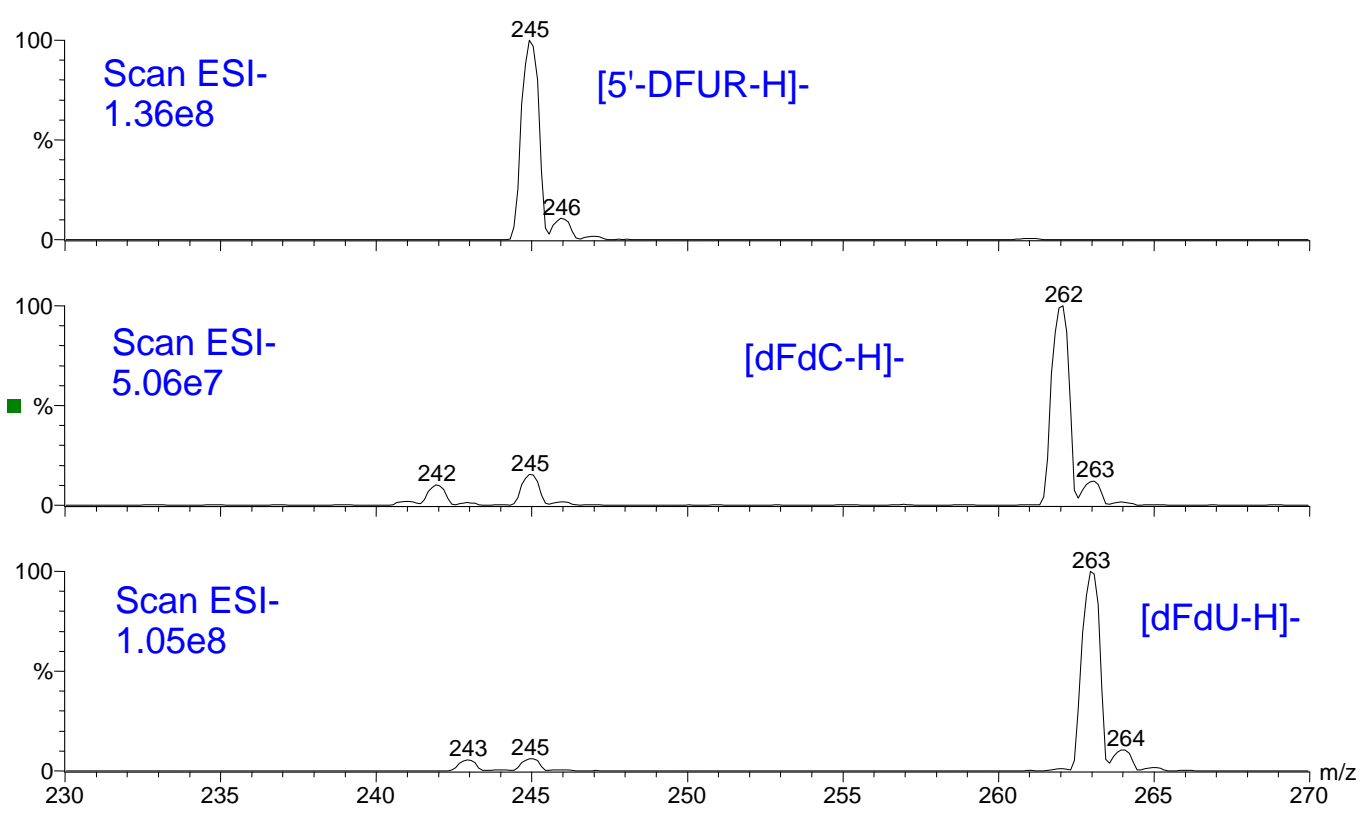

Fig. 3. The full-scan mass spectra of $\mathrm{dFdC}, \mathrm{dFdU}$ and 5'-DFUR (I.S.). Experimental conditions were described in Section 2.6.
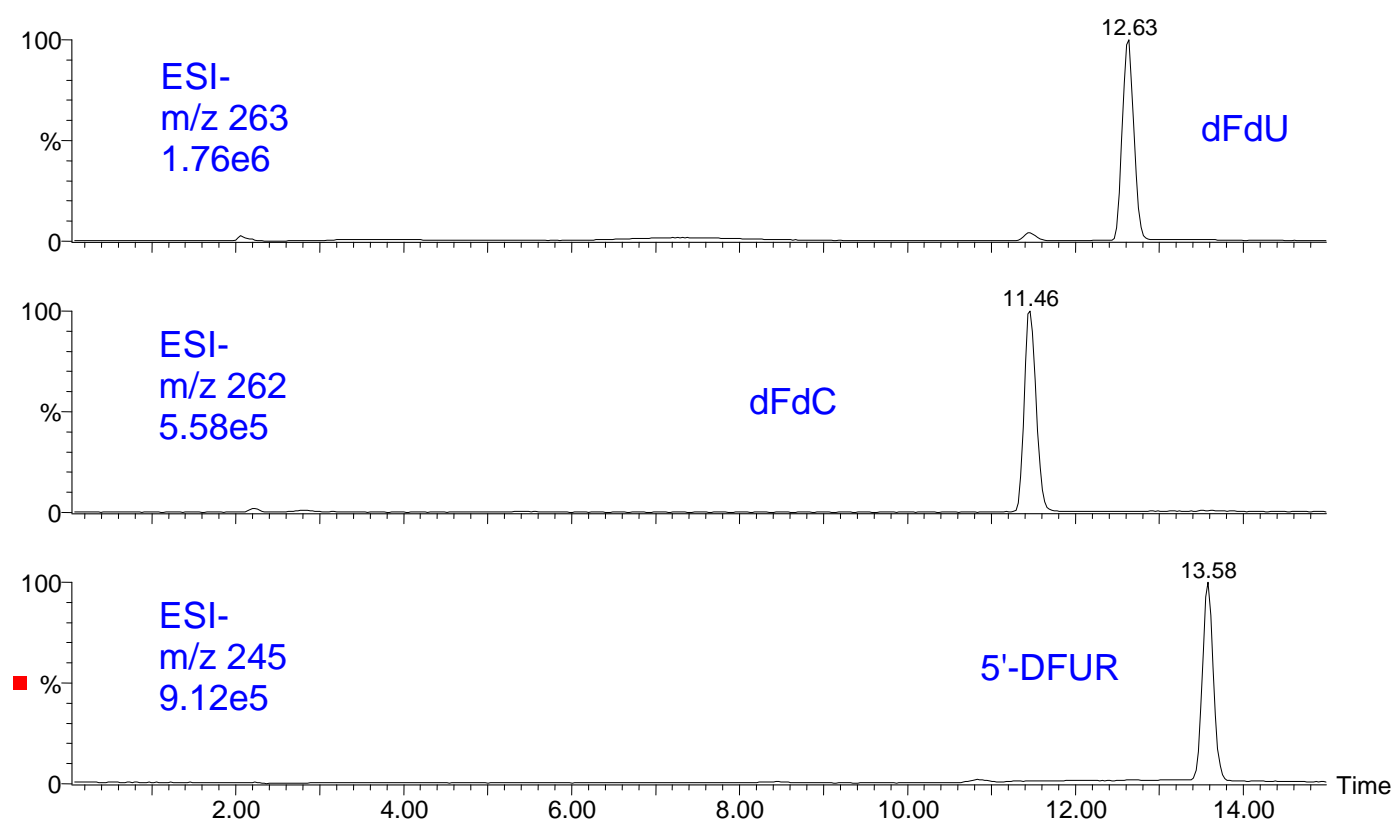

Fig. 4. Representative SIM chromatograms of $\mathrm{dFdC}, \mathrm{dFdU}$ and $5^{\prime}$-DFUR in human plasma. Experimental conditions were described in Sections 2.5 and 2.6. Analyte concentration: $500 \mathrm{ng} / \mathrm{ml}$.

Table 1

Recovery of dFdC, dFdU and I.S. in human plasma $(n=3)$

\begin{tabular}{|c|c|c|c|c|c|c|}
\hline \multirow[t]{2}{*}{ Analyte } & \multicolumn{2}{|l|}{$50(\mathrm{ng} / \mathrm{ml})$} & \multicolumn{2}{|l|}{$500(\mathrm{ng} / \mathrm{ml})$} & \multicolumn{2}{|l|}{$5000(\mathrm{ng} / \mathrm{ml})$} \\
\hline & $\%$ Recovery & $\% \mathrm{CV}$ & $\%$ Recovery & $\% \mathrm{CV}$ & $\%$ Recovery & $\% \mathrm{CV}$ \\
\hline $\mathrm{dFdC}$ & 89.0 & 7 & 89.4 & 2 & 86.8 & 0.5 \\
\hline $\mathrm{dFdU}$ & 84.6 & 1 & 82.2 & 2 & 86.9 & 0.6 \\
\hline I.S. $^{\text {a }}$ & 102 & 1 & 98.3 & 3 & 97.5 & 6 \\
\hline
\end{tabular}

a I.S. (5'-DFUR) is at the fixed concentration of $500 \mathrm{ng} / \mathrm{ml}$.

\subsection{Intra- and inter-assay precision}

The intra- and inter-assay precisions of the method were determined by analyzing blank plasma samples spiked with known concentrations of $\mathrm{dFdC}$ and $\mathrm{dFdU}(50.0,500$, $5000 \mathrm{ng} / \mathrm{ml}$ ). Three replicates were analyzed at each concentration level within a single run and from runs performed on three different days. The results for $\mathrm{dFdC}$ and $\mathrm{dFdU}$, as well as $5^{\prime}$-DFUR, in human plasma were shown in Table 2. The percent coefficients of variation $(\% \mathrm{CVs})$ for $\mathrm{dFdC}$, 
Table 2

The intra-and inter-assay precision of plasma samples $(n=3)$

\begin{tabular}{|c|c|c|c|c|c|c|c|c|c|}
\hline \multirow[t]{2}{*}{ Analyte } & \multicolumn{3}{|c|}{$50.0(\mathrm{ng} / \mathrm{ml})$} & \multicolumn{3}{|c|}{$500(\mathrm{ng} / \mathrm{ml})$} & \multicolumn{3}{|c|}{$5000(\mathrm{ng} / \mathrm{ml})$} \\
\hline & Peak area & S.D. & $\% \mathrm{CV}$ & Peak area & S.D. & $\% \mathrm{CV}$ & Peak area & S.D. & $\% \mathrm{CV}$ \\
\hline \multicolumn{10}{|c|}{ Intra-assay } \\
\hline $\mathrm{dFdC}$ & 11173 & 31 & 0.3 & 103912 & 1742 & 2 & 900129 & 2677 & 0.3 \\
\hline $\mathrm{dFdU}$ & 42502 & 412 & 1 & 313349 & 2769 & 0.9 & 1952863 & 12551 & 0.6 \\
\hline I.S. $^{\mathrm{a}}$ & 117098 & 1064 & 0.9 & 109613 & 3723 & 3 & 125194 & 626 & 0.5 \\
\hline \multicolumn{10}{|c|}{ Inter-assay } \\
\hline $\mathrm{dFdC}$ & 12101 & 796 & 7 & 103394 & 2059 & 2 & 892685 & 4512 & 0.5 \\
\hline $\mathrm{dFdU}$ & 42394 & 403 & 1 & 310931 & 5813 & 2 & 1950760 & 11800 & 0.6 \\
\hline I.S. $^{\mathrm{a}}$ & 118517 & 1605 & 1 & 113374 & 2912 & 3 & 125538 & 700 & 6 \\
\hline
\end{tabular}

a I.S. (5'-DFUR) is at the fixed concentration of $500 \mathrm{ng} / \mathrm{ml}$.

$\mathrm{dFdU}$ and $5^{\prime}$-DFUR were $\leq 3 \%$ for the intra-assay analyses and $\leq 7 \%$ for the inter-assay analyses.

\section{Linear calibration range}

The linear relationships were found between the peak-area ratios of $\mathrm{dFdC}$ and $\mathrm{dFdU}$ to internal standard $5^{\prime}$-DFUR over the concentration range $5-1000 \mathrm{ng} / \mathrm{ml}$ for $\mathrm{dFdC}$, and $5-5000 \mathrm{ng} / \mathrm{ml}$ for $\mathrm{dFdU}$. The typical regression equations were $Y=(0.001815) X-0.000311$ for $\mathrm{dFdC}$, and $Y=$ $(0.004306) X+0.033209$ for $\mathrm{dFdU}$ with correlation coefficients $\geq 0.998$ for both $\mathrm{dFdC}$ and $\mathrm{dFdU}$.

\section{Sensitivity and limits of quantitation}

Fig. 5 shows the detection sensitivity during SIM for dFdC and $\mathrm{dFdU}$. The signal-to-noise ratio by root mean square for $0.5 \mathrm{ng} \mathrm{dFdC}$ and $\mathrm{dFdU}$ were equal to 32 and 74 . The limits of quantitation were $3.16 \mathrm{ng} / \mathrm{ml}$ for plasma $\mathrm{dFdC}$ and $1.35 \mathrm{ng} / \mathrm{ml}$ for plasma $\mathrm{dFdU}$ with $50-\mu 1$ sample injections. These limits of quantitation were at least 15-37 times lower than those of the LC-UV methods [5,6].

\section{Clinical and pharmacokinetic results}

The validated assay was used to determine plasma concentrations of $\mathrm{dFdC}$ and $\mathrm{dFdU}$ in a Phase I trial of weekly $\mathrm{dFdC}$ given as 24-h infusion followed by 24-h infusion of
FUDR. The first three patients received a starting dose of $150 \mathrm{mg} / \mathrm{m}^{2} \mathrm{dFdC}$. As none of these patients could tolerate more than two weekly doses due to grade 2 mucositis and grade 3 fatigue (one patient) or grade 3 thrombocytopenia (two patients), the dose was decreased to $100 \mathrm{mg} / \mathrm{m}^{2}$. At the lower dose, one patient withdrew from the study after receiving a single dose for personal reasons; another patient experienced small bowel obstruction due to tumor requiring surgical bypass and received only one dose. One patient experienced grade 4 neutropenia after two doses of $\mathrm{dFdC}$, but tolerated the subsequent cycle at a reduced dose of $60 \mathrm{mg} / \mathrm{m}^{2}$. Two patients received all three weekly doses, but experienced grade 3 neutropenia that required a dose reduction to $80 \mathrm{mg} / \mathrm{m}^{2}$ for the second cycle. The toxicity observed with the 24-h infusion was felt to be prohibitive, and this schedule was abandoned.

The pharmacokinetic parameters of $\mathrm{dFdC}$ and $\mathrm{dFdU}$ from eight patients receiving their initial 24-h dFdC infusion are summarized in Table 3. There were no significant differences on the average plasma concentrations $\left(C_{\mathrm{p}}\right)$ between the values of 22- and 23-h infusion, which were consistent with achievement of steady-state concentrations. The average $C_{\mathrm{p}}$ for $\mathrm{dFdC}$ during cycle one for 150 and $100 \mathrm{mg} /\left(\mathrm{m}^{2} 24 \mathrm{~h}\right)$ were 18.3 and $16.8 \mathrm{ng} / \mathrm{ml}$, respectively, while the average $C_{\mathrm{p}}$ for $\mathrm{dFdU}$ were 2950 and $1372 \mathrm{ng} / \mathrm{ml}$. The ratios of $\mathrm{dFdU}$ to $\mathrm{dFdC}$ in the 24-h dFdC infusion study were much greater than those we previously determined with shorter infusion times of 1- and 2-h [6]. The area under the curve $\left(\mathrm{AUC}_{\text {last }}\right)$

Table 3

The pharmacokinetic parameters of $\mathrm{dFdC}$ and $\mathrm{dFdU}$ during initial gemcitabine infusion

\begin{tabular}{|c|c|c|c|c|c|c|c|c|c|}
\hline \multirow{4}{*}{$\begin{array}{l}\text { Gemcitabine } \\
\left(\mathrm{mg} /\left(\mathrm{m}^{2} 24 \mathrm{~h}\right)\right)\end{array}$} & \multirow[t]{4}{*}{ Patients } & \multicolumn{7}{|c|}{ Average \pm S.D. } & \multirow{4}{*}{$\begin{array}{l}\text { Median clearance } \\
\left(\mathrm{ml} /\left(\min \mathrm{m}^{2}\right)\right)\end{array}$} \\
\hline & & \multicolumn{2}{|c|}{$\mathrm{AUC}_{\text {last }}(\mu \mathrm{g} /(\mathrm{ml} \mathrm{min}))$} & \multicolumn{4}{|l|}{$C_{\mathrm{p}}(\mathrm{ng} / \mathrm{ml})$} & \multirow[t]{3}{*}{ Ratio $\mathrm{dFdU}$ to $\mathrm{dFdC}^{\mathrm{a}}$} & \\
\hline & & \multirow[t]{2}{*}{$\mathrm{dFdC}$} & \multirow[t]{2}{*}{$\mathrm{dFdU}$} & \multicolumn{2}{|l|}{$\mathrm{dFdC}$} & \multicolumn{2}{|l|}{$\mathrm{dFdU}$} & & \\
\hline & & & & $22 \mathrm{~h}$ & $23 \mathrm{~h}$ & $22 \mathrm{~h}$ & $23 \mathrm{~h}$ & & \\
\hline 150 & 3 & $12.1 \pm 2.9$ & $2020 \pm 399$ & $19.9 \pm 4.4$ & $16.7 \pm 4.7$ & $2845 \pm 558$ & $3055 \pm 781$ & $160.9 \pm 11.5$ & $\begin{array}{l}5961(25 \%, 3988 ; \\
75 \%, 8703)\end{array}$ \\
\hline 100 & 5 & $10.3 \pm 5.8$ & $916 \pm 333$ & $16.0 \pm 9.0$ & $17.6 \pm 10.4$ & $1266 \pm 438$ & $1477 \pm 590$ & $128.0 \pm 90.9$ & \\
\hline
\end{tabular}

${ }^{a}$ The 22- and 23-h values for $\mathrm{dFdC}$ and $\mathrm{dFdU}$ were averaged before calculating the ratio. 

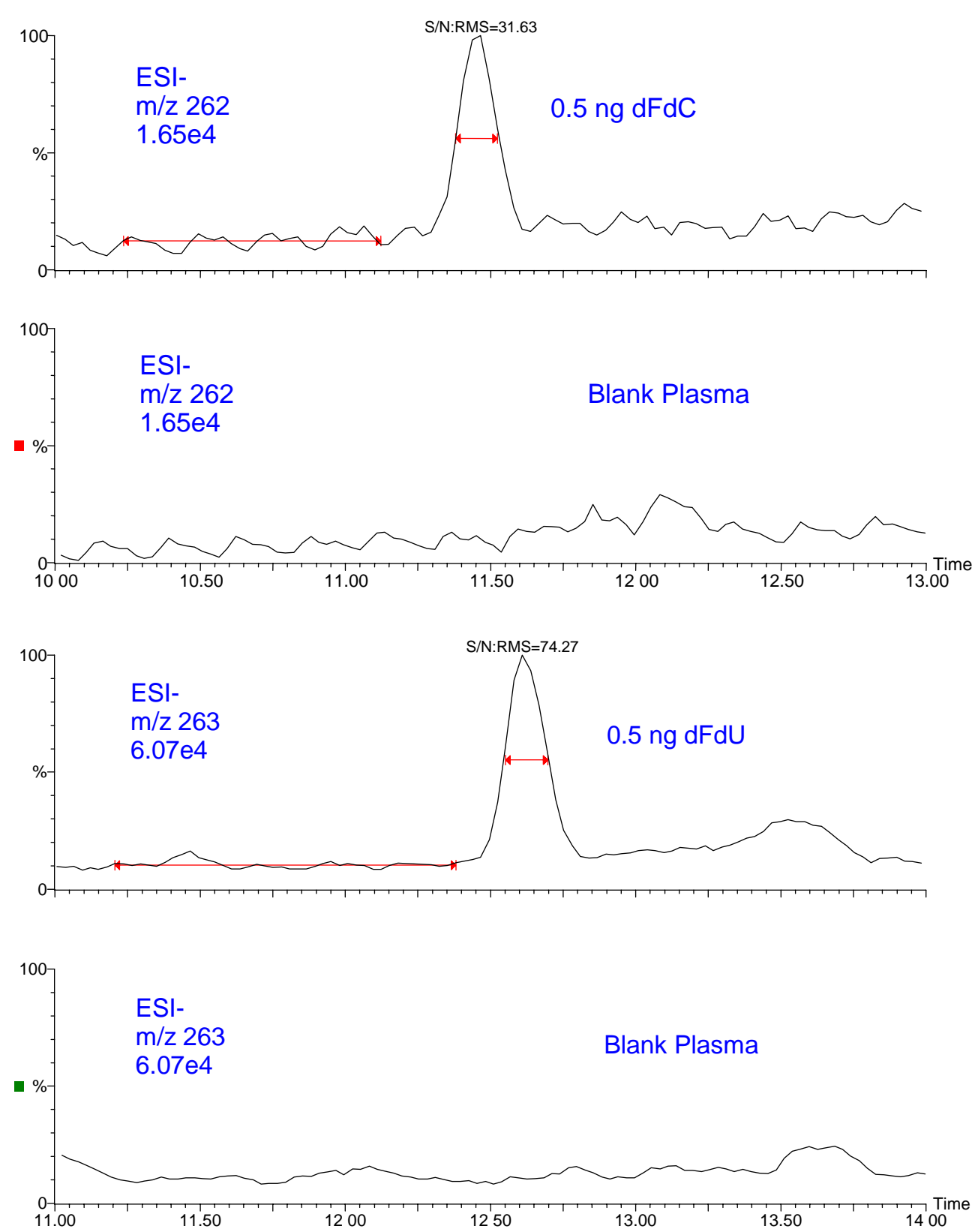

Fig. 5. The SIM chromatograms of blank plasma and plasma spiked with known concentrations of $\mathrm{dFdC}$ and dFdU. Experimental conditions were the same as in Fig. 4. Analyte concentration: $10 \mathrm{ng} / \mathrm{ml}$; injection volume $50 \mu \mathrm{l} ; 0.5 \mathrm{ng}$ injected.

at dose levels of 150 and $100 \mathrm{mg} /\left(\mathrm{m}^{2} 24 \mathrm{~h}\right)$ were 12.1 and $10.3 \mu \mathrm{g} /(\mathrm{ml} \mathrm{min})$ for $\mathrm{dFdC}$, and 2020 and $916 \mu \mathrm{g} /(\mathrm{ml} \mathrm{min})$ for $\mathrm{dFdU}$. The medium clearance was $5961 \mathrm{ml} /\left(\mathrm{min} \mathrm{m}^{2}\right)$.

\section{Conclusions}

An LC-MS method has been developed and validated for the determination of $\mathrm{dFdC}$ and $\mathrm{dFdU}$ at low concentrations in human plasma. This method uses solid-phase extraction for plasma sample preparation, reversed-phase LC for analyte separation, and electrospray ionization mass spectrometry for analyte quantitation. It employs an internal standard for calibration and offers shorter chromatographic separation time (15 min), and improved limits of quantitation for plasma $\mathrm{dFdC}$ and $\mathrm{dFdU}$. This method has been proven useful in a Phase I trial of weekly $\mathrm{dFdC}$ given as 24-h infusion, where the concentrations of $\mathrm{dFdC}$ were lower than or near the limits of quantitation of the LC-UV methods. Although we do not recommend further evaluation of the 24-h infusion schedule of gemcitabine, this LC-MS method offers advantages over the LC-UV methods in terms of shorter run times and greater sensitivity, and may prove useful in the analysis of limited volume biological samples and tissue pharmacokinetics. 


\section{Acknowledgements}

Dr. Yan Xu's one-year sabbatical at the National Cancer Institute was funded through an Interagency Personnel Agreement between the National Cancer Institute and Cleveland State University.

\section{References}

[1] V. Heinemann, Y.Z. Xu, S. Chubb, A. Sen, L.W. Hertel, G.B. Grindey, W. Plunkett, Mol. Pharmacol. 38 (1990) 567.

[2] B.J.M. Braakhuis, G.A.M.S. van Dongen, J.B. Vermorken, G.B. Snow, Cancer Res. 51 (1991) 211.

[3] S. Noble, K.L. Goa, Drugs 54 (1997) 447.

[4] J.L. Grem, B. Keith, in: M.R. Alison (Ed.), Cancer Handbook, Macmillan Press, London, 2002, p. 1271.
[5] K.B. Freeman, S. Anliker, M. Hamilton, D. Osborne, P.H. Dhahir R. Nelson, S.R.B. Allerheiligen, J. Chromatogr. B 665 (1995) 171.

[6] B. Keith, Y. Xu, J.L. Grem, J. Chromatogr. B 785 (2003) 65.

[7] J.L. Abbruzzese, R. Grunewald, E.A. Weeks, D. Gravel, T. Adams, B. Nowak, S. Mineishi, P. Tarassoff, W. Satterlee, M.N. Raber, W. Plunkett, J. Clin. Oncol. 9 (1991) 491.

[8] A.P. Venook, M.J. Egorin, G.L. Rosner, D. Hollis, S. Mani, M. Hawkins, J. Byrd, R. Hohl, D. Budman, N.J. Meropol, M.J. Ratain, J. Clin. Oncol. 18 (2000) 2780.

[9] G. Veerman, V.W. Ruiz van Haperen, J.B. Vermorken, P. Noordhuis, B.J. Braakhuis, H.M. Pinedo, G. Peters, Cancer Chemother. Pharmacol. 38 (1996) 335.

[10] Q.F. Ren, V. Kao, J.L. Grem, Clin. Cancer Res. 4 (1998) 2811.

[11] R. Grunewald, J.L. Abbruzzese, P. Tarassoff, W. Plunkett, Cancer Chemother. Pharmacol. 27 (1991) 258.

[12] V. Heinemann, Y.Z. Xu, S. Chubb, A. Sen, L.W. Hertel, G.B. Grindey, W. Plunkett, Cancer Res. 52 (1992) 533.

[13] Y. Xu, J.L. Grem, J. Chromatogr. B 783 (2003) 273. 